\title{
Dietary separation between two blennies and the Pacific gregory in northern Taiwan: evidence from stomach content and stable isotope analyses
}

\author{
Cheng-Tze Ho $\cdot$ Shuh-Ji Kao $\cdot$ Chang-Feng Dai · Hwey-Lian Hsieh · \\ Fuh-Kwo Shiah $\cdot$ Rong-Quen Jan
}

Received: 25 May 2006/ Accepted: 11 October 2006/Published online: 3 November 2006

(C) Springer-Verlag 2006

\begin{abstract}
Two blennies, Ecsenius lineatus Klausewitz and Ecsenius namiyei (Jordan and Evermann), and a cohabiting territorial damselfish, the Pacific gregory, Stegastes fasciolatus (Ogilby), were collected from shallow reefs in northern Taiwan between September and November 2004, and in October 2005 for stomach content and $\delta^{13} \mathrm{C}$ and $\delta^{15} \mathrm{~N}$ analyses in an effort to study how extensively their food sources overlapped and to delineate the pattern of cohabiting interactions. These analyses showed differences in food use between the Ecsenius blennies and S. fasciolatus. However, there were inconsistencies. Epiphytic algae were their major food items of E. namiyei and E. lineatus. Macroalgae were rarely taken. Nevertheless, $\delta^{13} \mathrm{C}$ and $\delta^{15} \mathrm{~N}$ signatures suggested that $E$. namiyei and $E$. lineatus might have assimilated mainly macroalgae-derived detritus instead of epiphytic algae. In contrast, macroalgae were the major food items of $S$. fasciolatus, followed by epiphytic algae. Differences in both $\delta^{13} \mathrm{C}$ and ${ }^{15} \mathrm{~N}$ values indicated that for $S$. fasciolatus, algae (both macroalgae and epiphytic algae) might not be as important as the stomach contents showed. Instead,
\end{abstract}

Communicated by S. Nishida, Tokyo.

C.-T. Ho - C.-F. Dai

Institute of Oceanography, National Taiwan University,

Taipei 106, Taiwan, ROC

S.-J. Kao · F.-K. Shiah

Research Center for Environmental Changes,

Academia Sinica, Taipei 115, Taiwan, ROC

H.-L. Hsieh · R.-Q. Jan ( ()

Research Center for Biodiversity, Academia Sinica,

Taipei 115, Taiwan, ROC

e-mail: rqjan@gate.sinica.edu.tw polychaetes were possibly its major food source. Differences between stomach contents and evidence from the separation of stable isotope signatures between blennies and the Pacific gregory indicate that some of the interspecific interactions derived from exploitative competition may have been alleviated. Moreover, their widespread territory overlap is possibly a sign of mutualism: $S$. fasciolatus allows territory sharing, while Ecsenius blennies, in return, clean up the algal mat by removing sand and detritus.

\section{Introduction}

Blennies and damselfishes are common inhabitants of shallow reefs. Many blennies feed on a mixed diet of algae and benthic invertebrates; some are planktivores, and some are specialized to feed on scales or mucus of larger fishes, while damselfishes have a varied diet, which includes benthic algae but also zooplankton and benthic invertebrates (Hobson 1974; Randall et al. 1990; Cleveland and Montgomery 2003). Some blennies and damselfishes hold territories (Horn 1989; Ceccarelli et al. 2001). These fishes have attracted further attention because territories defended by the blennies often lie within, or overlap with, the larger territories of damselfishes (Low 1971; Roberts 1987; Townsend and Tibbetts 2004).

Several studies on interspecific interactions between blennies and territorial damselfish have focused on their food uses. For example, in removal experiments conducted on One Tree Reef, the Great Barrier Reef, Roberts (1987) found little difference in food use and no evidence of either exploitation 
competition or interference between the damselfish Pomacentrus chrysurus Cuvier (as Pomacentrus flavicauda Whitley) and blennies, primarily Salarias fasciatus Bloch, and suggested that territorial damselfishes might tolerate blennies grazing within their territories because they could not effectively exclude them. By contrast, Townsend and Tibbetts (2004) proposed that competition between the damselfish Pomacentrus wardi Whitley and S. fasciatus might not be over algal components, but instead over the attached detritus, as along with algal components, both fishes might take a large proportion of detrital food (Wilson and Bellwood 1997; Wilson 2000). In addition, they noted that $P$. wardi tended to tolerate the grazing of blennies within its territory because the latter contributed to territorial defense from other blennies. To resolve such arguments, a clearer picture of their diet composition is needed. Knowledge of what fraction of the epilithic algal community (EAC) each species assimilates would also be helpful in explaining ecological interactions between these cohabiting fish species.

In this study, we collected specimens of two blennies, Ecsenius lineatus Klausewitz and E. namiyei (Jordan and Evermann), and the cohabiting Pacific gregory, Stegastes fasciolatus (Ogilby), a territorial damselfish, in order to study their diet composition. Their stomach contents were examined, and stable carbon and nitrogen isotopes were measured in fish muscle tissues and in potential food items collected from their habitats. Based on the efficiency of using stable isotope analysis (Polunin et al. 2001; Vizzini and Mazzola 2003), we hoped to properly identify the food sources of each fish species, despite different fish species possibly feeding on the same EAC but assimilating different components. From the aspect of feeding interactions, the results of this study may thus help elucidate factors involved in the coexistence of blennies and territorial damselfishes in reef systems.

\section{Materials and methods}

Fieldwork was carried out at Longdong Bay $\left(25^{\circ} 06^{\prime} \mathrm{N}\right.$, $121^{\circ} 55^{\prime}$ E) in north-eastern Taiwan between September and November 2004 (for collection I), and in October 2005 (for collection II). The study site is shallow (with depths of 1-7 m), and the substratum is composed of rocky reef, rubble, and sand. Two species of Ecsenius blenny (i.e., E. lineatus and E. namiyei) and a territorial damselfish (Pacific gregory, Stegastes fasciolatus) inhabit small patches on the reef. Habitats of these two blennies and damselfish were often found to overlap. In addition, $S$. fasciolatus showed no aggression toward either of the two Ecsenius species (unpublished data).

Ecsenius lineatus (collection I: $n=10,1.9-6.1 \mathrm{~cm}$ in standard length, SL; collection II: $n=10,3.8-5.6 \mathrm{~cm}$ in SL) and E. namiyei (I: $n=10,1.3-7.4 \mathrm{~cm}$ in SL; II: $n=14,4.7-6.2 \mathrm{~cm}$ in SL) were collected by handnetting. Stegastes fasciolatus (I: $n=26,3.2-11.5 \mathrm{~cm}$ in SL; II: $n=11,5.7-9.6 \mathrm{~cm}$ in SL) was collected by selective angling. All collections were conducted by scuba divers. Specimens were kept in ice water slurry in sealed plastic bags and transported immediately to the laboratory, where, for each specimen, standard length was measured $( \pm 1 \mathrm{~mm})$ using calipers, stomach was removed and preserved in $10 \%$ buffered formalin solution for content analysis, and white dorsal muscle tissue, which tends to be less variable in $\delta^{13} \mathrm{C}$ and $\delta^{15} \mathrm{~N}$ values than other tissues (Pinnegar and Polunin 1999) and is widely used in food-web studies (Pinnegar and Polunin 2000; Deudero et al. 2004), was taken and frozen for later stable isotope analysis.

Potential food items were sampled from habitats of these three fish species. To ensure that all material in the EAC was retained in samples, plastic click-seal bags were placed over algal mats when the algal community was removed. The bags were sealed and the contents returned to the lab for processing (Wilson and Bellwood 1997). The samples were mainly comprised of macroalgae (including Ceramium flaccidium, Chaetomorpha spiralis, Cheilosporum acutilobum, Eucheuma serra, Gelidium amansii, Meristotheca papulosa, Rhodopeltis borealis, and Ulva lactuca), epiphytic algae (algae growing on the macroalgae; sorted under a stereomicroscope and categorized into red, black, or green by the color), and invertebrates [including gastropods (Monodonta labio and Euplica versicolor), polychaetes, and amphipods (Eupronon spp.)]. Detritus was added to the sample in collection II by collecting detrital aggregates on algal fronds through a pipe using suction (D. R. Bellwood, personal communication). Carbonates in invertebrate and detritus samples were removed with $1 \mathrm{~N} \mathrm{HCl}$ (Boutton 1991) before further treatment.

Stomach contents were spread on slides, and its components were identified using a stereomicroscope. Food items were categorized into macroalgae, epiphytic algae, diatoms, amphipods, polychaetes, fish eggs, detritus, sand, and unidentifiable matter. The relative volumetric quantity of each food item was estimated using the point frame method (Hyslop 1980; Jan et al. 1994; Wilson 2004). In collection I, three individuals of E. lineatus and two of E. namiyei, collected early in the morning in rough seas, had empty 
stomachs. Otherwise, stomach contents of all fish specimens were analyzed.

Muscle tissues of fish specimens and food samples were freeze-dried (at $-53^{\circ} \mathrm{C}$ for $48 \mathrm{~h}$ ) and ground up with a mortar and pestle. Acidified samples (1-2 mg) were combusted in an elemental analyzer (Flash EA$1100 \mathrm{NC}$, Thermo-Finnigan) to produce $\mathrm{CO}_{2}$ and $\mathrm{N}_{2}$, which flowed through a GC column for separation and into a mass spectrometer (Thermo Finnigan Delta ${ }^{\text {plus }}$ Advantage) for separately determining isotopic compositions. Isotope ratios were expressed as the difference in parts per thousand $(\%)$ from standard reference material:

$\delta X=\left[\left(R_{\text {sample }} / R_{\text {standard }}\right)-1\right] \times 1,000$,

where $X$ is ${ }^{13} \mathrm{C}$ or ${ }^{15} \mathrm{~N}, R$ is the corresponding ratio of ${ }^{13} \mathrm{C}:{ }^{12} \mathrm{C}$ or ${ }^{15} \mathrm{~N}:{ }^{14} \mathrm{~N}$, and $\delta$ is a measure of the heavy to light isotopes in the sample. The reference materials were the international standards, Pee Dee Belemnite (PDB) for carbon and atmospheric $\mathrm{N}_{2}$ for nitrogen.

Wilcoxon matched-pairs test was used to test for dietary differences between the two collections in each fish species. The dietary overlap between fish species was determined using Schoener's index $(\alpha)$, which varies from 0 , representing no overlap, to 1 , representing complete overlap between species (Schoener 1970). Values of 0.6 or greater are considered as biologically significant overlap (Martin 1984). (Data on the unidentified portion of the stomach contents were excluded in both the above analyses.) Differences in $\delta^{13} \mathrm{C}$ and $\delta^{15} \mathrm{~N}$ values among the three fish species were tested by analysis of covariance (ANCOVA) using fish body length as the covariate. Blennies were further divided into different size-groups based on frequency distribution histograms to illustrate the potential trophic effect on stable isotope-body size relationship. The non-parametric Kruskal-Wallis test was used to test for differences among potential food items.

\section{Results}

Stomach content analysis

Dietary data combined from the two collections are presented because for any fish species, the difference between collections was not significant (Fig. 1; Wilcoxon matched pairs test, E. lineatus: $n=8, T=11$, $P=0.61 ;$ E. namiyei: $n=8, T=7, P=0.24 ; S$. fasciolatus, $n=8, T=15, P=0.67)$. Ecsenius lineatus and E. namiyei consumed similar foods $(\alpha=0.95)$. Epiphytic algae were the major food items identified (with mean volumetric percentages of 30.0 and $25.9 \%$, respectively), followed by sand (24.9 and $24.6 \%)$ and detritus (21.0 and 20.4\%). Macroalgae, diatoms, amphipods, and polychaetes were relatively rare. No fish eggs were found in the stomachs of either blenny. Meanwhile, large portions of unidentified matter occurred in both species (14.6 and 13.8\%). In blennies, significant positive correlations occurred between detrital food and body length (E. lineatus: $r=0.53$, $P=0.03 ;$ E. namiyei: $r=0.54, P<0.01)$.

Stegastes fasciolatus also consumed epiphytic algae $(18.2 \%)$. But its major food item was macroalgae ( $30.9 \%)$, followed by detritus $(11.5 \%)$. It also fed on fish eggs $(4.7 \%)$. In contrast to the blennies, this damselfish consumed more diatoms ( 8.8 vs. $4.8 \%$ and $4.8 \%$ ), polychaetes (7.1 vs. $1.5 \%$ and $1.6 \%$ ), and amphipods (5.0 vs. $1.7 \%$ and $2.1 \%$ ), and less detritus $(11.5 \%)$, sand $(5.1 \%)$, and unidentified matter $(8.5 \%)$ compared to Ecsenius lineatus and E. namiyei, respectively. The dietary overlap index $(\alpha)$ between E. lineatus and $S$. fasciolatus was 0.50 ; and was 0.55 between $E$. namiyei and $S$. fasciolatus.

Stable isotopes

\section{Fishes}

Different ranges of stable isotope values were found in different fish species in different collections. The $\delta^{13} \mathrm{C}$ values in Ecsenius lineatus ranged from -15.0 to $-12.2 \%$ in collection $\mathrm{I}$, and from -14.3 to $-12.4 \%$ in collection II. In E. namiyei, $\delta^{13} \mathrm{C}$ values ranged from -16.9 to $-12.2 \%$ in collection $\mathrm{I}$, and from -15.3 to $-13.1 \%$ in collection II. In Stegastes fasciolatus, $\delta^{13} \mathrm{C}$ values ranged from -16.2 to $-14.6 \%$ in collection $\mathrm{I}$, and from -15.4 to $-14.4 \%$ in collection II.

The $\delta^{15} \mathrm{~N}$ values in Ecsenius lineatus ranged from 6.9 to $9.2 \%$ in collection I and from 7.6 to $8.9 \%$ in collection II. In E. namiyei, $\delta^{15} \mathrm{~N}$ values ranged from 7.5 to $9.8 \%$ in collection I and from 8.3 to $8.9 \%$ in collection II. In Stegastes fasciolatus $\delta^{15} \mathrm{~N}$ values ranged from 9.6 to $11.4 \%$ in collection I and from 9.4 to $10.7 \%$ in collection II.

Results of the ANCOVA showed that the $\delta^{13} \mathrm{C}$ and $\delta^{15} \mathrm{~N}$ values shared a common pattern: both were positively related to the covariate fish body length ( $d f=1$ and $74, P<0.001$ for either isotope) and were affected by the fish species examined $(d f=2$ and 74 , $P<0.001$ for either isotope). By contrast, there was no significant effect of collection $\left(\delta^{13} \mathrm{C}: d f=1\right.$ and 74 , $P=0.98 ; \delta^{15} \mathrm{~N}: d f=1$ and $\left.74, P=0.15\right)$, and no significant interaction between fish and collection $\left(\delta^{13} \mathrm{C}\right.$ : $d f=2$ and $74, P=0.20 ; \delta^{15} \mathrm{~N}: d f=2$ and $\left.74, P=0.17\right)$. 
Fig. 1 Stomach content analyses for Ecsenius lineatus, E. namiyei and Stegastes fasciolatus in two collections. Error bars are standard errors
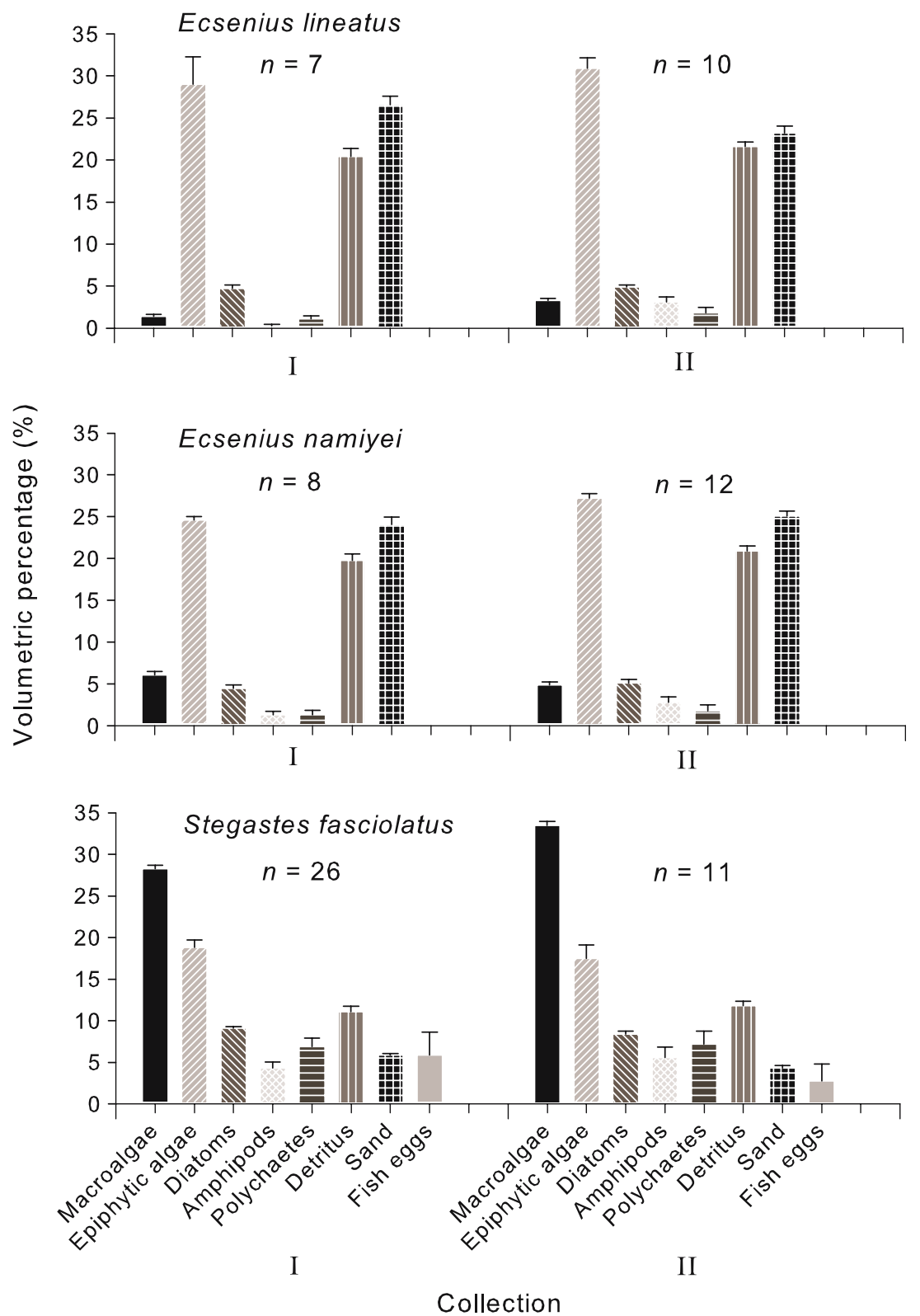

Linear relationships between $\delta$ values of the stable isotopes and SL of the fish are presented in Fig. 2 for ${ }^{13} \mathrm{C}$ and Fig. 3 for ${ }^{15} \mathrm{~N}$.

Blennies were further divided into two size-groups (small body size, $\mathrm{S}$, and large body size, $\mathrm{L}$, respectively) using $4 \mathrm{~cm}$ in SL as a divider. For each size-group the data were plotted against the prey/diet stable isotope signatures to illustrate the trophic effect on stable isotope-body size relationship (Fig. 4). The group means were: collection I, E. lineatus, $\delta^{13} \mathrm{C}:-12.7 \%$ (L) and $-13.7 \%$ (S), $\delta^{15} \mathrm{~N}: 8.6 \%$ (L) and $7.5 \%(\mathrm{~S}), E$. namiyei, $\delta^{13} \mathrm{C}:-12.9 \%$ (L) and $-14.6 \%$ (S), $\delta^{15} \mathrm{~N}: 9.1 \%$ (L) and $8.1 \%$ (S); collection II, E. lineatus, $\delta^{13} \mathrm{C}$ : $-13.2 \%$ (L) and $-13.4 \%$ (S), $\delta^{15} \mathrm{~N}: 8.3 \%$ (L) and $7.9 \%$
(S), E. namiyei, $\delta^{13} \mathrm{C}:-14.0 \%$ (L), $\delta^{15} \mathrm{~N}: 8.5 \%$ (L) (small specimens unavailable).

\section{Potential food items}

All eight species of macroalgae were examined in collection I (Fig. 4). Their $\delta^{13} \mathrm{C}$ values ranged from $-17.9 \%$ (Rhodopeltis borealis) to $-14.9 \%$ (Chaetomorpha spiralis). Also three types of epiphytic algae were examined, with $\delta^{13} \mathrm{C}$ values ranging from $19.7 \%$ (green color) to $-18.3 \%$ (red color). The $\delta^{13} \mathrm{C}$ values of invertebrates examined ranged from $-17.8 \%$ (amphipods) to $-14.6 \%$ (gastropods). In collection II, five species of macroalgae were examined, with $\delta^{13} \mathrm{C}$ 


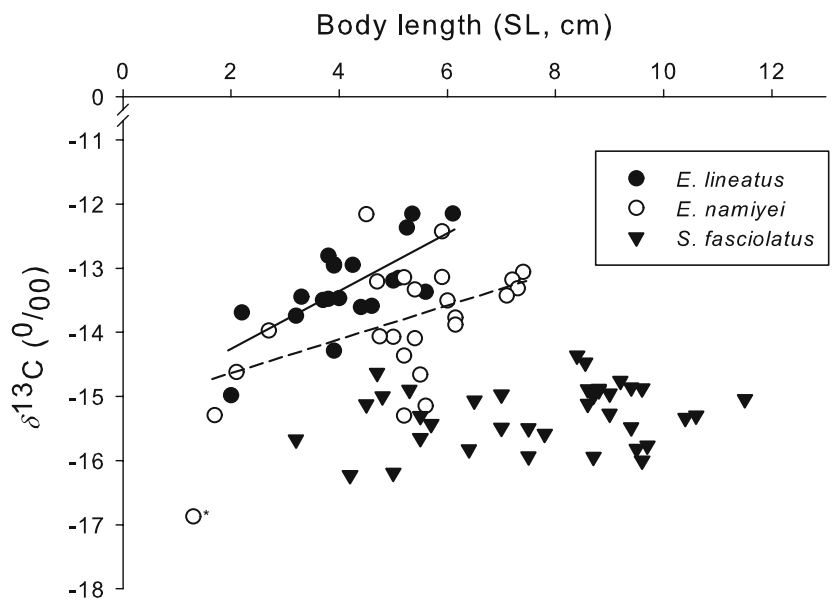

Fig. 2 Relationship between body length $(S L)$ and $\delta^{13} \mathrm{C}$ of Ecsenius lineatus (long line), E. namiyei (short dash line), and Stegastes fasciolatus. The line was fitted by: E. lineatus, $y=0.4 x-15.8\left(n=20, r^{2}=0.51, P<0.001\right)$; and $E$. namiyei, $y=0.5 x-15.2\left(n=23, r^{2}=0.20, P=0.03\right)$. Asterisk Excluded from the linear regression

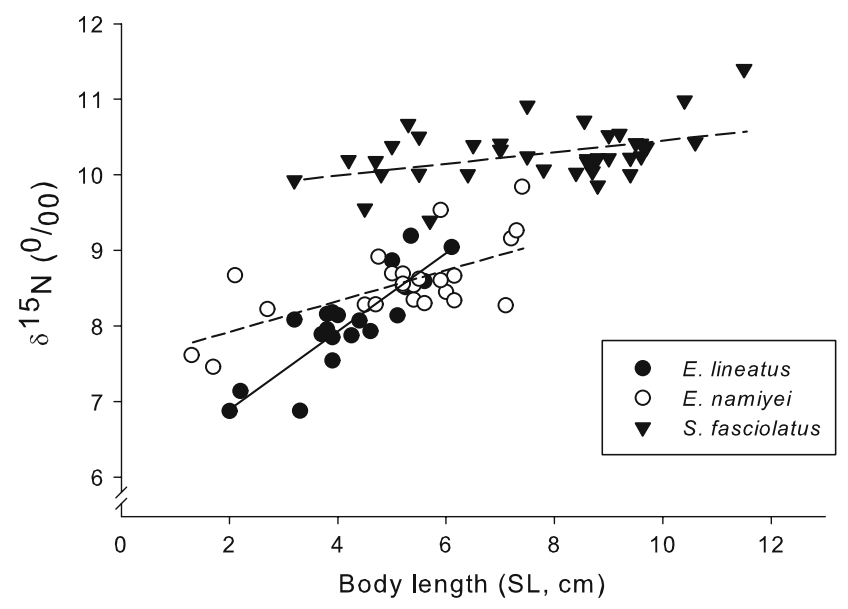

Fig. 3 Relationship between body length $(S L)$ and $\delta^{15} \mathrm{~N}$ of Ecsenius lineatus (long line), E. namiyei (short dash line), and Stegastes fasciolatus (medium dash line). The line was fitted by: E. lineatus, $y=0.2 x+7.5 \quad\left(n=20, r^{2}=0.73, P<0.001\right) ; E$. namiyei, $y=0.5 x+5.9\left(n=24, r^{2}=0.45, P<0.001\right)$; and $S$. fasciolatus, $y=0.1 x+9.7\left(n=37, r^{2}=0.20, P<0.01\right)$

values ranging from $-16.0 \%$ (Meristotheca papulosa) to $-13.9 \%$ (Cheilosporum acutilobum) (Fig. 4). Also two types of epiphytic algae were examined, and their $\delta^{13} \mathrm{C}$ values ranged from $-17.7 \%$ (red color) to $-17.4 \%$ (black color). The $\delta^{13} \mathrm{C}$ values of invertebrates ranged from $-17.3 \%$ (amphipods) to $-16.5 \%$ (polychaetes). The mean $\delta^{13} \mathrm{C}$ value of detritus was $-15.7 \%$.

The $\delta^{15} \mathrm{~N}$ values of algae as a whole (totally 11 species/types) in collection I ranged from $4.4 \%$

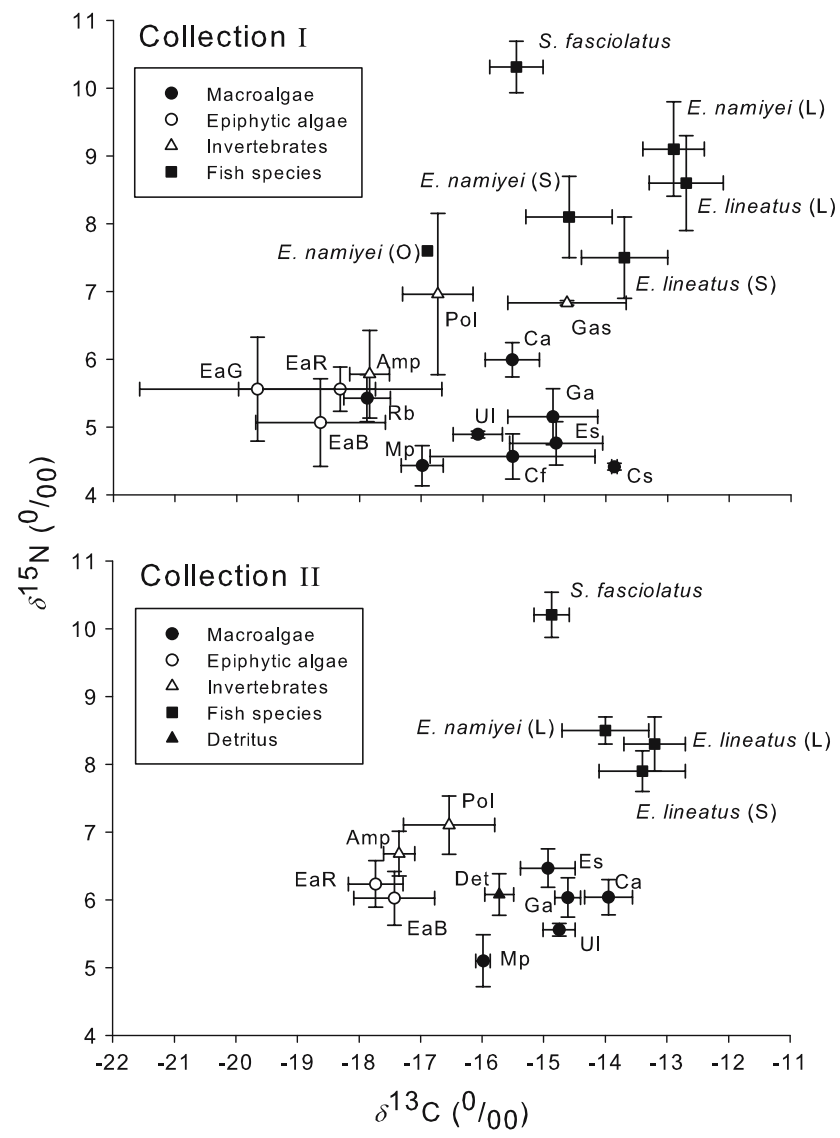

Fig. 4 Mean $( \pm$ SD) carbon and nitrogen isotope values of Ecsenius lineatus, E. namiyei, and Stegastes fasciolatus and potential food items in two collections. Macroalgae: $\mathrm{Ca}$, Cheilosporum acutilobum; Cf, Ceramium flaccidium; Cs, Chaetomorpha spiralis; Es, Eucheuma serra; Ga, Gelidium amansii; $\mathrm{Mp}$, Meristotheca papulosa; Rb, Rhodopeltis borealis; and U1, Ulva lactuca. Epiphytic algae: EaR, epiphytic algae (red); EaB, epiphytic algae (black); and $\mathrm{EaG}$, epiphytic algae (green). Invertebrates: Gas, gastropods; Pol, polychaetes; and Amp, amphipods. Fishes: (L), body size equal or larger than $4.0 \mathrm{~cm}$ in SL; (S), body size smaller than $4.0 \mathrm{~cm}$ in SL except for $(\mathrm{O})$; (O), body size of $1.3 \mathrm{~cm}$ in SL. Detritus: Det

(Chaetomorpha spiralis) to $6.0 \%$ (Cheilosporum acutilobum). The $\delta^{15} \mathrm{~N}$ values of the invertebrate categories ranged from 5.8\% (amphipods) to 7.0\% (polychaetes). In collection II, $\delta^{15} \mathrm{~N}$ values of algae as a whole (totally seven species/types) ranged from $5.1 \%$ (Meristotheca papulosa) to 6.5\% (Eucheuma serra). The $\delta^{15} \mathrm{~N}$ values of invertebrate categories ranged from $6.7 \%$ (amphipods) to $7.1 \%$ (polychaetes). The mean $\delta^{15} \mathrm{~N}$ value of detritus was $6.1 \%$. In both collections significant differences were found in $\delta^{13} \mathrm{C}$ between macroalgae and epiphytic algae (Kruskal-Wallis, I: $H=11.2, \quad d f=1, \quad P<0.01 ; \quad$ II: $\quad H=12.96, \quad d f=1$, $P=0.02)$, but not in $\delta^{15} \mathrm{~N} \quad(\mathrm{I}: H=2.42, d f=1$, $P=0.12$; II: $H=0.08, d f=1, P=0.76$ ). 


\section{Discussion}

Diet composition of blennies

In general, increases in $\delta^{13} \mathrm{C}$ of $1-2 \%$ and in $\delta^{15} \mathrm{~N}$ of $3.4 \%( \pm 1 \%$, SD $)$ are expected to occur between consumers and their food resources (Minagawa and Wada 1984; Wada et al. 1991; Post 2002). Stomach content analyses showed that these blennies preferred epiphytic algae. However, except for the smallest individual (1.3 cm in SL, Fig. 4), this did not concur with their $\delta^{13} \mathrm{C}$ signatures, because the $3.7 \%$ (Ecsenius namiyei, S) to $5.6 \%$ (E. lineatus, L) (collection I) and $3.4 \%$ (E. namiyei, L) to $4.5 \%$ (E. lineatus, L) (collection II) differences between blennies and epiphytic algae (Fig. 4) were much higher than the expected 1$2 \%$. Since macroalgae constituted very little of the diet for the two blennies, their $\delta^{13} \mathrm{C}$ signatures may have reflected the high detrital component of the diet (Fig. 1). The enrichments in $\delta^{13} \mathrm{C}$ of $1.8-2.4 \%$ and in $\delta^{15} \mathrm{~N}$ of $2.1-2.5 \%$ between blennies and detritus (collection II in Fig. 4) have lent support to this notion. Moreover, the detritus might have mainly derived from macroalgae, as indicated by the overlap of both $\delta^{13} \mathrm{C}$ and $\delta^{15} \mathrm{~N}$ values from the detritus and macroalgae examined in collection II (Fig. 4).

Stomach content analyses showed that the two blennies rarely fed on invertebrates. Similar results were obtained from the stable isotope analyses as the smallest increase in $\delta^{13} \mathrm{C}$ between blennies and amphipods was $3.2 \%$ (small Ecsenius namiyei in collection II), higher than the $1-2 \%$ expected in a consumer-food source relation and the largest increase in $\delta^{15} \mathrm{~N}$ was $2.1 \%$ (E. namiyei, L, collection I) between blennies and polychaetes and $2.3 \%$ (E. namiyei, L, collection I) between blennies and gastropods, both much smaller than the $3.4 \%$ for a trophic level difference.

Overall, the present results indicate that Ecsenius lineatus and E. namiyei are both detritivores. At Lizard Island, Great Barrier Reef, the salariin blenny, Salarias patzneri, was also found to ingest more detritus than any other dietary category including filamentous algae (Wilson 2000). As widely occurring detritivores on reefs, blennies represent a significant linkage between detritus and secondary consumers and therefore play an important role in reef trophodynamics (Wilson 2004).

\section{Diet composition of the Pacific gregory}

The diet and organic sources of Stegastes fasciolatus were less variable. A high proportion (i.e., 49.1\%) of stomach contents of $S$. fasciolatus was algae (including macroalgae and epiphytic algae). However, the smallest difference in $\delta^{15} \mathrm{~N}$ between $S$. fasciolatus and algae (including both macroalgae and epiphytic algae) was $4.3 \%$ in collection I and $3.7 \%$ in collection II, both higher than that of the per-trophic level increase $(3.4 \%$ ). Therefore, as an organic source, algae as a whole might not have been as important to $S$. fasciolatus as might be inferred from examination of stomach contents.

Like some other 'herbivorous' damselfishes, e.g., Stegastes planifrons (Lobel 1980) and S. nigricans (Letourneur et al. 1997), S. fasciolatus also feeds on benthic invertebrates. Attention is particularly drawn to polychaetes, which made up $7.1 \%$ of the stomach content (c.f. $2 \%$ in Hawaii; Hobson 1974), because the $1.7-1.8 \%$ depletion of $\delta^{13} \mathrm{C}$ values and $3.1-3.3 \%$ depletion of $\delta^{15} \mathrm{~N}$ values of polychaetes in the collections (Fig. 4) suggested that polychaetes might have been the major organic source for $S$. fasciolatus. Other invertebrates might have played a minor role, as indicated by their deviations from polychaetes in terms of stable isotope signatures. Conventional stomach content analysis might have underestimated the nutritive contributions of polychaetes in contrast to other invertebrates, because while the animals are rapidly digested, the undigested chaetae were too minute to be observed with dissecting microscopes due to the resolution limit (Hyslop 1980; Hsieh 1995).

In northern Taiwan, farming behaviors of territorial damselfishes such as Stegastes nigricans and S. lividus (Randall et al. 1990) were not observed in S. fasciolatus. The territory of $S$. fasciolatus could only be moderately defined, not by any distinct difference in algal growth (e.g., S. nigricans territory, Jan et al. 2003), but by a series of concentric territorial boundaries defended against heterospecific intruders (unpublished data). Conventionally, algal food was assumed to be the prime resource defended by permanent-territorial damselfishes. However, the present results indicate that the priority of defending territory by $S$. fasciolatus was possibly to secure polychaetes, which use the algal mat as shelter in the daytime, rather than the algal mat itself.

\section{Implications of dietary separations}

The relationship presented in Figs. 2 and 3 strongly indicate that both Ecsenius lineatus and E. namiyei have very little food resource overlap with Stegastes fasciolatus, and that they have significantly different trophic niches within this particular food-web. In the two Ecsenius blennies, both $\delta^{13} \mathrm{C}$ and $\delta^{15} \mathrm{~N}$ signatures were positively linked to body length. In the stomach contents, a significant positive relationship also occurred between detrital food and body length. Benthic $\delta^{13} \mathrm{C}$ signatures have been demonstrated to be highly 
variable (Hecky and Hesslein 1995), smaller, younger individuals of many fish species are more susceptible to predation and often utilize different habitats than larger, older individuals (Werner et al. 1977; Weaver et al. 1997). While the territorial damselfish might provide protection for the blennies sharing the territory, the role the damselfish plays on the foraging of these blennies and the influence on stable isotope signatures within blenny species also needs scrutiny. Moreover, the positive links could have been caused by an ontogenetic dietary shift (Cocheret de la Morinière et al. 2003; Deudero et al. 2004; Paterson et al. 2006), or by different isotopic fractionations in fish of different ages (Pinnegar and Polunin 1999; Overman and Parrish 2001). By contrast, the $\delta^{13} \mathrm{C}$ and $\delta^{15} \mathrm{~N}$ relationships depicted for Stegastes fasciolatus suggest this damselfish have extremely high prey/food resource fidelity and little trophic variability, regardless of body size.

In coral reef systems the EAC consists of a mixture of epilithic algae, sediment, detritus, and invertebrates (Wilson and Bellwood 1997). In this study the EAC concept was applied to rocky reef systems with the coverage of both macroalgae and epiphytic algae.

Since Stegastes fasciolatus and the Ecsenius blennies feed on different food items from the EAC, they might have avoided exploitative competition by this dietary separation. This may explain their coexistence in reef environments. The depleted $\delta^{13} \mathrm{C}$ in polychaetes in collection II (Fig. 4) suggests that the macroalgae-derived detritus exploited by the blennies would not have been the organic source for polychaetes, the potential dietary resource for $S$. fasciolatus. Thus, interference over dietary resources was not expected to occur between these cohabiting fishes. Moreover, by combining the above findings, their widespread territory overlap is possibly a sign of mutualism: $S$. fasciolatus allows territory sharing and provides protection and, in return, Ecsenius blennies clean up the algal mat by removing sand and detritus.

Acknowledgments We thank Y.H. Liu and Y.T. Shao for their help with the fieldwork. This research was funded by grants (NSC90-2311-B-001-161 and NSC93-2311-B-001-051) from the National Science Council of the Republic of China and the Research Center for Biodiversity, Academia Sinica. The experiments complied with the current laws of the country in which they were performed.

\section{References}

Boutton TW (1991) Stable carbon isotope ratios of natural materials: I. Sample preparation and mass spectrometric analysis. In: Coleman DC, Fry B (eds) Carbon isotope techniques. Academic, San Diego, pp 155-171
Ceccarelli DM, Jones GP, McCook (2001) Territorial damselfishes as determinants of the structure of benthic communities on coral reefs. Oceanogr Mar Biol Annu Rev 39: 355-389

Cleveland A, Montgomery W (2003) Gut characteristics and assimilation efficiencies in two species of herbivorous damselfishes (Pomacentridae: Stegastes dorsopunicans and S. planifrons). Mar Biol 142:35-44

Cocheret de la Morinière E, Pollux BJA, Nagelkerken I, Hemminga MA, Huiskes AHL, van der Velde G (2003) Ontogenetic dietary changes of coral reef fishes in the mangrove-seagrass-reef continuum: stable isotopes and gutcontent analysis. Mar Ecol Prog Ser 246:279-289

Deudero S, Pinnegar JK, Polunin NVC, Morey G, Morales-Nin B (2004) Spatial variation and ontogenic shifts in the isotopic composition of Mediterranean littoral fishes. Mar Biol 145:971-981

Hecky RE, Hesslein RH (1995) Contributions of benthic algae to lake food webs as revealed by stable isotope analysis. J North Am Benthol Soc 14:631-653

Hobson ES (1974) Feeding relationships of teleostean fishes on coral reef in Kona, Hawaii. Fish Bull 72:915-1031

Horn MH (1989) Biology of marine herbivorous fishes. Oceanogr Mar Biol Annu Rev 27:167-272

Hsieh HL (1995) Spatial and temporal patterns of polychaete communities in a subtropical mangrove swamp: influences of sediment and microhabitat. Mar Ecol Prog Ser 127: 157-167

Hyslop EJ (1980) Stomach content analysis-a review of methods and their application. J Fish Biol 17:411-429

Jan RQ, Dai CF, Chang KH (1994) Monitoring of hard substrate communities. In: Kramer KJM (ed) Biomonitoring of coastal waters and estuaries. CRC, Boca Raton, pp 285-310

Jan RQ, Ho CT, Shiah FK (2003) Determinants of territory size of the dusky gregory. J Fish Biol 63:1589-1597

Letourneur Y, Galzin R, Harmelin-Vivien M (1997) Temporal variations in the diet of the damselfish Stegastes nigricans (Lacepède) on a Réunion fringing reef. J Exp Mar Biol Ecol 217:1-18

Lobel PS (1980) Herbivory by damselfishes and their role in coral reef community ecology. Bull Mar Sci 30:273-289

Low RM (1971) Interspecific territoriality in a pomacentrid reef fish, Pomacentrus flavicauda Whitley. Ecology 52:648-654

Martin FD (1984) Diet of four sympatric species of Etheostoma (Pisces: Percidae) from southern Indiana: interspecific and intraspecific multiple comparisons. Environ Biol Fishes 11:113-120

Minagawa M, Wada E (1984) Stepwise enrichment of ${ }^{15} \mathrm{~N}$ along food chains: further evidence and the relation between $\delta^{15} \mathrm{~N}$ and animal age. Geochim Cosmochim Acta 48:1135-1140

Overman NC, Parrish DL (2001) Stable isotope composition of walleye: ${ }^{15} \mathrm{~N}$ accumulation with age and area-specific differences in $\delta^{13} \mathrm{C}$. Can J Fish Aquat Sci 58:1253-1260

Paterson G, Drouillard KG, Haffner GD (2006) Quantifying resource partitioning in centrarchids with stable isotope analysis. Limnol Oceanogr 51:1038-1044

Pinnegar JK, Polunin NVC (1999) Differential fractionation of $\delta^{13} \mathrm{C}$ and $\delta^{15} \mathrm{~N}$ among fish tissues: implications for the study of trophic interactions. Funct Ecol 13:225-231

Pinnegar JK, Polunin NVC (2000) Contributions of stableisotope data to elucidating food webs of Mediterranean rocky littoral fishes. Oecologia 122:399-409

Polunin NVC, Morales-Nin B, Pawsey WE, Cartes JE, Pinnegar JK, Moranta J (2001) Feeding relationships in Mediterranean bathyal assemblages elucidated by stable nitrogen and carbon isotope data. Mar Ecol Prog Ser 220:13-23 
Post DM (2002) Using stable isotopes to estimate trophic position: models, methods, and assumptions. Ecology 83:703-718

Randall JE, Allen GR, Steene RC (1990) Fishes of the Great Barrier Reef and Coral Sea. Crawford House Press, Bathurst

Roberts CM (1987) Experimental analysis of resource sharing between herbivorous damselfish and blennies on the Great Barrier Reef. J Exp Mar Biol Ecol 111:61-75

Schoener TW (1970) Non-synchronous spatial overlap of lizards in patchy habitats. Ecology 51:408-418

Townsend KA, Tibbetts IR (2004) The ecological significance of the combtoothed blenny in a coral reef ecosystem. J Fish Biol 65:77-90

Vizzini S, Mazzola A (2003) Seasonal variations in the stable carbon and nitrogen isotope ratios $\left({ }^{13} \mathrm{C} /{ }^{12} \mathrm{C}\right.$ and $\left.{ }^{15} \mathrm{~N} /{ }^{14} \mathrm{~N}\right)$ of primary producers and consumers in a western Mediterranean coastal lagoon. Mar Biol 142:1009-1018
Wada E, Mizutani H, Minagawa M (1991) The use of stable isotopes for food web analysis. Crit Rev Food Sci Nutr 30:361-371

Weaver MJ, Magnuson JJ, Clayton KM (1997) Distribution of littoral fishes in structurally complex macrophytes. Can J Fish Aquat Sci 54:2277-2289

Werner EE, Hall DJ, Laughlin DR, Wagner DJ, Wilsmann LA, Funk FC (1977) Habitat partitioning in a freshwater fish community. J Fish Res Board Can 34:360-370

Wilson SK (2000) Trophic status and feeding selectivity of blennies (Blenniidae: Salariini). Mar Biol 136:431-437

Wilson SK (2004) Growth, mortality and turnover rates of a small detritivorous fish. Mar Ecol Pro Ser 284:253-259

Wilson SK, Bellwood DR (1997) Cryptic diet composition of territorial damselfish (Pomacentridae, Labroidei). Mar Ecol Prog Ser 153:299-310 